\title{
Improving PPKN Learning Outcomes through Class IV Discovery Learning Learning Model SD Negeri 1 Adisana
}

\author{
Nur Hasanah \\ SDN 1 ADISANA \\ hnur51631@gmail.com
}

\section{Article History \\ accepted 01/11/2020}

approved 08/11/2020

\begin{abstract}
Improving PPKn Learning Outcomes through Class IV Discovery Learning Model SD Negeri 1 Adisana is a research conducted to improve learning outcomes of PPKn Class IV SD Negeri 1 Adisana, material about environmental impacts that are not maintained, this is done because the learning outcomes of students' formative test scores are still low. The research was carried out by applying the discoveru learning model with the group discussion method in PPKn lessons. The study was conducted in 3 cycles, because researchers expect student learning outcomes to increase by up to 90 percent. The research was carried out with the help of colleagues as observers. Based on the results of reflection in cycle I student learning outcomes increased to 74.1 percent, where in the pre-cycle only 37 percent of students completed. Then in cycle 2 it increased to 96.3 percent then in cycle 3 it increased to 100 percent. Based on these results, the application of the discovery learning model improves the learning outcomes of fourth grade students in the PPKn subject matter that is not maintained environmental impact.
\end{abstract}

Keywords: Learning outcomes, discussion, discovery learning.

\begin{abstract}
Abstrak
Peningkatan Hasil Belajar PPKn Melalui Model Pembelajaran Discovery Learning Kelas IV SD Negeri 1 Adisana adalah penelitian yang dilakukan untuk meningkatkan hasil belajar PPKn Kelas IV SD Negeri 1 Adisana materi tentang dampak lingkungan yang tidak dijaga, hal tersebut dilakukan karena hasil belajar nilai tes formatif siswa masih rendah. Penelitian dilaksanakan dengan menerapkan model discoveru learning dengn metode diskusi kelompok dalam pelajaran PPKn. Penelitian dilakukan dengan 3 siklus, karena peneliti mengharapkan hasil belajar siswa meningkat hingga 90 persen. Penelitian dilaksanakan dengan bantuan teman sejawat sebagai observer. Berdasarkan hasil refleksi pada siklus I hasil belajar siswa meningkat menjadi 74,1 persen yang dimana pada pra siklus hanya 37 persen siswa yang tuntas. Kemudian pada siklus 2 meningkat hingga 96,3 persen kemudian pada siklus 3 meningkat hingga 100 persen. Kemudian pada siklus 3 untuk hasil belajar mencapai 100 persen, sikap peduli terhadap lingkungan 100 persen dan untuk keterampilan berkomunikasi meningkat menjadi 96,29 persen. Berdasarkan hasil tersebut maka penerapan model discovery learning dapat meningkatkan hasil belajar siswa kelas IV pada mata pelajaran PPKn materi dampak lingkungan yang tidak dijaga.
\end{abstract}

Kata kunci: Hasil belajar,diskusi,discovery learning.

Social, Humanities, and Education Studies (SHEs): Conference Series https://jurnal.uns.ac.id/shes

p-ISSN 2620-9284 e-ISSN 2620-9292 


\section{PENDAHULUAN}

Dalam pembelajaran PPKn materi tentang dampak lingkungan yang tidak dijaga Kelas IV SD Negeri 1 Adisana Kecamatan Kebasen Kabupaten Banyumas, sebagian besar peserta didik kurang aktif dan kurang berfikir kritis sehingga apabila anak menghadapi masalah kontekstual baru yang berbeda dengan yang dicontohkan, anak belum mampu berfikir kritis dan menemukan solusi dengan benar sehingga banyak anak yang menjawab salah. Hal tersebut menyebabkan apabila diadakan tes, nilai pelajaran PPKn selalu rendah dengan rata - rata kurang dari KKM yang telah ditentukan, dari data yang ditemukan dari 27 peserta didik yang nilainya diatas KKM baru 10 anak.

Menghadapi kenyataan tersebut di atas, peneliti tertarik untuk mendalami dan melakukan tindakan - tindakan perbaikan pembelajaran PPKn, khususnya materi Dampak lingkungan yang tidak dijaga melalui penelitian tindakan kelas. Perbaikan yang penulis lakukan mengenai penerapan metode diskusi dengan menggunakan model discovery learning pada materi Dampak lingkungan yang tidak dijaga. Harapan peneliti adalah terjadinya pembelajaran aktif, kreatif dan menyenangkan serta lebih bermakna dan adanya keberanian peserta didik yang tuntas untuk menyelesaikan masalah kontektual dengan benar serta untuk lebih menguasai dan memahami pelajaran.

Berdasarkan identifikasi masalah di atas, peneliti berusaha mencari faktor penyebab masalah dengan melakukan refleksi, bertanya kepada peserta didik dan melakukan diskusi dengan teman sejawat. Dari hasil diskusi dapat disimpulkan bahwa penyebab peserta didik belum memahami materi Dampak Lingkungan Yang Tidak Dijaga adalah seperti berikut:

a. Sebagian peserta didik belum aktif dalam pembelajaran.

b. Kurangnya contoh dan latihan yang diberikan oleh guru.

c. Peserta didik kurang berfikir kritis dalam pembelajaran.

d. Hasil belajar peserta didik masih rendah

Berdasarkan temuan peneliti di atas maka peneliti akan melakukan penelitian tindakan kelas dengan metode diskusi dalam pembelajaran dengan model discovery learning, hal tersebut sesuai dengan pendapat dari Beberapa kelebihan metode penemuan juga diungkapkan oleh Suherman, dkk (2001: 179) sebagai berikut: 1. Siswa aktif dalam kegiatan belajar, sebab ia berpikir dan menggunakan kemampuan untuk menemukan hasil akhir; 2. Siswa memahami benar bahan pelajaran, sebab mengalami sendiri proses menemukannya. Sesuatu yang diperoleh dengan cara ini lebih lama diingat; 3. Menemukan sendiri menimbulkan rasa puas. Kepuasan batin ini mendorong ingin melakukan penemuan lagi sehingga minat belajarnya meningkat; 4. Siswa yang memperoleh pengetahuan dengan metode penemuan akan lebih mampu mentransfer pengetahuannya ke berbagai konteks.

Dengan menerapkan metode diskusi dengan menggunakan model discovery learning diharapkan hasil belajar siswa kelas IV SD Negeri 1 Adisana dapat meningkat sesuai dengan harapan peneliti yaitu hasil belajar peserta didik kelas IV dapat mencapai 90 persen lebih, dan peneliti akan berusaha untuk memperbaiki pembelajaran PPKn dengan menggunakan metode diskusi dengan model discovery learning yang dimana peserta didik akan dibagi menjadi 6 kelompok untuk melakukan diskusi guna menemukan penyelesaian dari masalah yang disajikan oleh peneliti sebagai bahan diskusi kelompok. Dengan demikian maka rumusan masalahnya adalah "Apakah metode diskusi dengan model Discovery Learning dapat meningkatkan hasil belajar peserta didik dalam materi tentang Dampak ingkungan yang tidak dijaga kelas IV SD Negeri 1 Adisana Kecamatan Kebasen Kabupaten Banyumas?" 
SHEs: Conference Series 3 (3) (2020) 384- 389

Sedangkan tujuan dari penelitian tindakan kelas adalah untuk mengetahui apakah metode diskusi dengan menggunakan model pembelajaran Discovery Learning dapat meningkatkan hasil belajar peserta didik dalam materi tentang Dampak ingkungan yang tidak dijaga.

\section{METODE}

Jenis penelitian yang dilakukan adalah merupakan penelitian tindakan kelas pada kelas IV SD Negeri 1 Adisana Kecamatan Kebasen Kabupaten Banyumas. Penelitian ini bertempat di SDN 1 Adisana Kecamatan Kebasen, Kabupaten Banyumas. Sedangkan Waktu penelitian pra siklus tanggal 10 Oktober 2020, siklus I dilaksanakan tanggal 21 Oktober 2020, siklus 2 dilaksanakan tanggal 26 Oktober 2020 sedangkan siklus 3 dilaksanakan pada tanggal 2 November 2020.

Alat yang digunakan dalam penelitian adalah butir soal yang tertuang didalam tes formatif yang berupa lembar evaluasi mata pelajaran PPKn materi tentang dampak lingkungan yang tidak dijaga. Kemudian teknik pengumpulan data dilakukan dengan lembar pengamatan yang diisi dan dibantu oleh teman sejawat sebagai observer.

Teknik validasi data menggunakan cara triangulasi. Data nilai siswa divalidasi instrumennya.Para kolabor memvalidasi isi instrumen tes. Caranya degan mecocokkan butir tes dengan kisi-kisi. Sedangkan data kualitatif proses pembelajaran divalidasi melalui dua kolabor yang berbeda, kemudian hasilnya dirata-rata.

Kemudian data nilai siswa dianalisis dengan teknik dirata-rata, kemudian dibandingkan dengan KKM.Selanjutnya, masing rata-rata datanilai dibandingkan antara kondisi awal, siklus 1, dan siklus 2.Data kualitas pembelajaran dianalisis melalui.Data kuantitatif diproses melalui analisis deskriptif, sedangkan data kualitatif akan diproses dalam bentuk narasi yang mencerminkan kualitas pembelajaran.

\section{HASIL DAN PEMBAHASAN}

Hasil penelitian yang dilakukan pada peserta didik kelas IV SD Negeri 1 Adisana, Kecamatan Kebasen, Kabupaten Banyumas terkait hasil belajar PPKn tentang Dampak Lingkungan Yang Tidak Dijaga, melalui metode diskusi dengan model pembelajaran Discovery Learning, yang dilaksanakan dalam perbaikan pembelajaran pada siklus I, siklus 2 dan siklus 3 secara lengkap dijabarkan sebagai berikut.

Tabel 1.1 Data peningkatan pada siklus 1,2 dan 3

\begin{tabular}{llllll}
\hline No & Aspek & Pra Siklus & Siklus 1 & Siklus 2 & Siklus 3 \\
\hline 1 & Hasil belajar & $37 \%$ & $74,10 \%$ & $96,30 \%$ & $100 \%$ \\
2 & $\begin{array}{l}\text { Sikap peduli terhadap } \\
\text { lingkungan }\end{array}$ & $33 \%$ & $70,40 \%$ & $100 \%$ & $100 \%$ \\
3 & $\begin{array}{l}\text { Keterampilan } \\
\text { berkomunikasi }\end{array}$ & $29,60 \%$ & $62,90 \%$ & $92,60 \%$ & $96,30 \%$ \\
\hline
\end{tabular}


Dari data di atas dapat diperjelas dengan grafik dibawah ini :

Grafik Peningkatan pada siklus 1, 2 dan 3

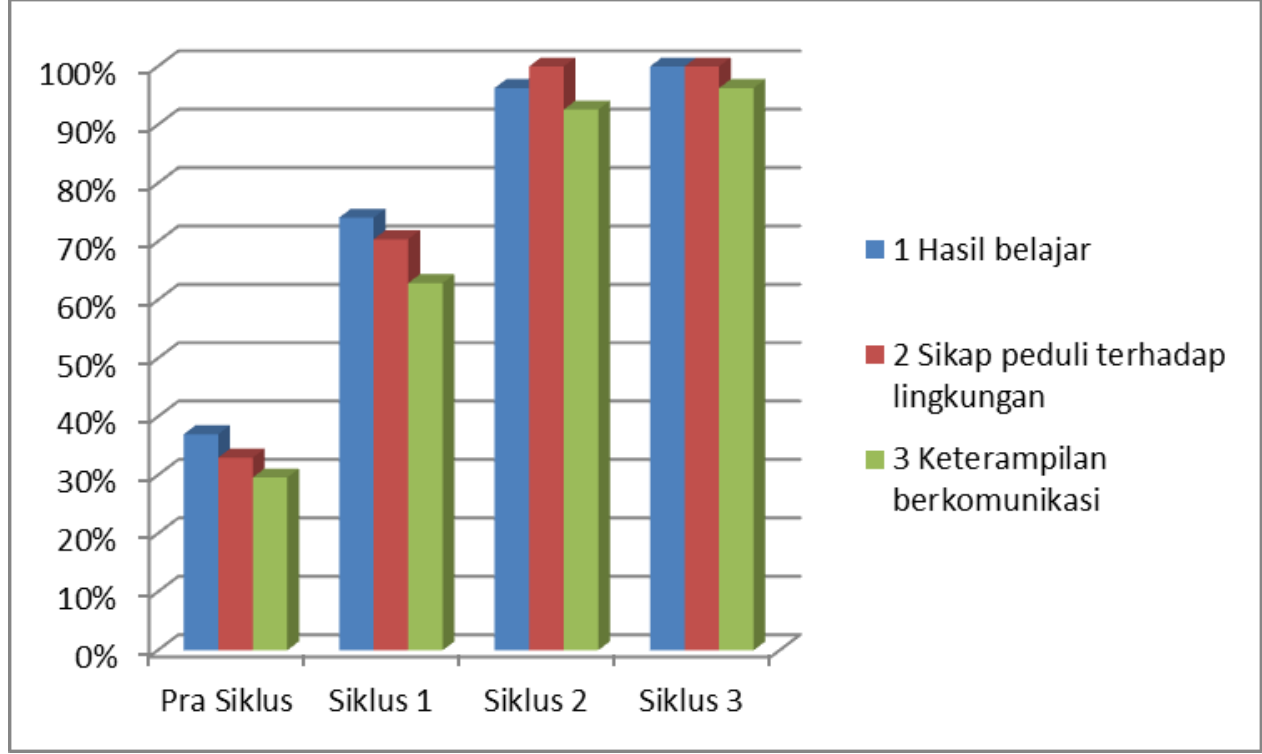

Berdasarkan tabel dan grafik diatas dapat terlihat dengan jelas bahwa telah terjadi peningkatan pada pembelajaran siklus 1, 2 dan siklus 3. Pada pembelajaran pra siklus hasil belajar peserta didik masih sangat rendah dengan pencapaian ketuntasan KKM hanya mencapai 37 persen dari 27 peserta didik yang ada. Melihat hal tersebut peneliti sangat prihatin, kemudian melalukan tindakan pada siklus I.

Pada pembelajaran pra siklus peneliti belum menggunakan metode diskusi dengan penggunaan model discovery learning, sehingga peserta didik belum begitu memahami materi yang disampaikan dan menyebabkan hasil belajar, sikap peduli terhadap lingkungan dan keterampilan dalam berkomunikasi peserta didik masih rendah. Kemudian pada siklus I peneliti sudah melalukan tindakan dengan perbaikan pembelajaran menggunakan metode diskusi dengan model discovery learning, dimana peserta didik di kelompokan menjadi 6 kelompok untuk berdiskusi menemukan pemcahan masalah yang disajikan oleh guru/peneliti.

Pada pembelajaran siklus I berdasarkan hasil pengamatan dari observer dapat terlihat dengan jelas bahwa telah terjadi peningkatan pada pembelajaran siklus I, hakl tersebut dapat terlihat dari hasil belajar peserta didik yang mencapai ketuntasan KKM mencapai 74,10 persen 27 peserta didik. Selain itu sikap peduli terhadap lingkungan juga sudah meningkat, hal tersebut dapat diamati dengan cerita peserta didik dalam pembelajaran tentang kegiatan mereka di rumah dalam usaha menjaga lingkungan, yang pada siklus I ini meningkat menjadi 70,40 persen. Sedangkat untuk keterampilan peserta didik dalam berkomunikasi mencapai 62, 90 persen pada siklus I. Berdasarkan hasil pada siklus I, hasil belajar, sikap peduli dan keterampilan berkomunikasi peserta didik sudah mengalami peningkatan namun peningkatan tersebut belum sesuai dengan harapan sehingga peneliti memutuskan untuk melanjutkan pada siklus 2 .

Berdasarkan hasil pengamatan dari observer pada pembelajaran siklus 2 yang dimana dalam pembelajaran PPKn menggunakan metode diskusi dengan penerapan model discovery learning, maka pada siklus 2 hasil belajar dan yang lainya mengalami peningkatan. Hal tersebut terlihat berdasarkan data hasil pengamatan yang menunjukan bahwa hasil belajar peserta didik telah meningkat menjadi 96,30 persen 
dari 27 peserta didik. Kemudian untuk sikap peduli terhadap lingkungan meningkat menjadi 100 persen dengan demikian dari 27 peserta didik sudah memiliki sikap peduli terhadap lingkungan. Kemudian untuk keterampilan berkomunikasi pada siklus 2 meningkat menjadi 92, 60 persen. Selain terjadi peningkatan yang cukup signifikan pada siklus 2, peserta didik juga terlihat antusias dalam mengikuti pembelajaran daring lewat zoom meeting. Selain itu peserta didik terlihat sangat aktif dalam pembelajaran, hal tersebut terbukti dan dapat dilihat dengan jelas saat sesi menanggapi kelompok yang lain. Pada sesi ini banyak sekali siswa yang mengajukan tanggapan maupun pertanyaan terhadap kelompok lain terkait dengan presentasi hasil diskusi yang disampaikan. Kemudian kelompok yang diberi tanggapan atau pertanyaanpun dapat dengan segera menjawab. Hal tersebut tentunya membuat peneliti merasa senang dan merasa sudah dapat meningkatkan pembelajaran pada siklus 2. Meskipun demikian peneliti masih penasaran dan ingin melanjutkan penelitian pada siklus 3 .

Pada siklus 3 peneliti membagi peserta didik menjadi 8 kelompok, dengan harapan keterampilan berkomununikasi peserta didik dapat meningkat lagi, sehingga peserta didik yang masih belum menyampaikan pendapatnya dalam diskusi maupun belum bertanya dan belum aktif dalam pembelajaran diharapkan dapat bersuara dan dapat aktif dalam pembelajaran. Selain itu bahan diskusi untuk masing-masing kelompok juga berbeda dan bervariasi dengan harapan masing-masing kelompok akan aktif dan dapat menemukan suatu pengetahuan yang baru dalam sesi presentasi dan sesi saling menanggapi anatar kelompok. Berdasarkan hasil pengamatan dari observer yang didiskusikan dengan peneliti maka data yang dihasilkan menunjukan peningkatan pada siklus 3 ini. Peningkatan tersebut sesuai dengan harapan peneliti yang dimana hasil peserta didik mencapai 100 persen demikian juga dengan sikap peduli terhadap lingkungan yang ternyata pada siklus 3 tidak mengalami penurunan. Kemudian untuk keterampilan berkomunikasi pada siklus 3 meningkat menjadi 96,30 persen, yang berarti dari 27 peserta didik yang ada hanya ada 1 siswa yang belum aktif dalam diskusi dan sesi tanggapan. Berdasarkan review yang dilakukan oleh peneliti peserta didik tersebut adalah peserta didik yang memiliki karakter pendian dan pemalu yang dimana memang baik dalam pembelajaran maupun dalam non pembelajaran bersikap diam dan jarang bersuara.

Melihat hasil yang demikian peneliti merasa senang, karena penelitian tindakan kelas yang dilakukan dengan bantuan observer hasilnya sudah menunjukan hasil yang diharapkan oleh peneliti. Apalagi peserta didik dan orang tua peserta didik terlihat begitu antusias pada pembelajaran melalui zoom meeting yang dilakukan oleh peneliti, selain itu peserta didik begitu aktif dan begitu semangat dalam pembelajaran. Melihat hal yang demikian peneliti memutuskan untuk tidak melanjutkan perbaikan pembelajaran pada siklus berikutnya dikarenakan peneliti sudah berhasil pada siklus 3 ini.

\section{SIMPULAN}

Setelah peneliti melaksanakan perbaikan pembelajaran melalui pembelajaran siklus I dan siklus 2 hingga siklus 3 dengan materi Dampak Lingkungan Yang tidak dijaga dikelas IV SDN 1 Adisana tahun pelajaran 2020/2021, Kecamatan Kebasen, Kabupaten banyumas, maka penulis dapat mengambil kesimpulan bahwa Peningkatan Hasil Belajar Mata Pelajaran Ppkn Materi Dampak Lingkungan Yang Tidak Dijaga Melalui Metode Diskusi Dengan Model Pembelajaran Discovery Learning Kelas IV SD Negeri 1 Adisana Kecamatan Kebasen Kabupaten Banyumas Semester I Tahun Pelajaran 2020/2021telah mampu meningkatkan hasil belajar siswa. 
SHEs: Conference Series 3 (3) (2020) 384- 389

Peningkatan ini terjadi pada siklus I maupun siklus 2 dengan bukti adanya peningkatan pada : Pelaksanaan pembelajaran PPKn materi Dampak Lingkungan yang tidak dijaga dengan menggunakan Metode Diskusi dan penggunaan Model Discovery Learning di kelas IV SDN 1 Adisana Kecamatan Kebasen Kabupaten Banyumas terbukti dapat meningkatkan hasil belajar siswa, hal ini berdasarkan hasil observasi terhadap aktivitas siswa dan jika dipersentasekan prasiklus $37 \%$, siklus 1 $74,1 \%$, pada siklus 2 naik lagi menjadi 96,3 \%. Selain itu penggunaan model pembelajaran discovery learning dengan metode diskusi dalam pembelajaran PPKn di kelas IV SDN 1 Adisana Kecamatan Kebasen Kabupaten Banyumas, terbukti dapat meningkatkan Perubahan sikap peduli siswa kelas IV terhadap lingkungan, hal ini dapat terlihat dari peningkatan data yang pada pembelajaran pra siklus $33 \%$, pada siklus 1 meningkat menjadi 70,4 dan pada siklus 2 menjadi 100 persen. Kemudian pada siklus 3 untuk hasil belajar mencapai 100 persen, sikap peduli terhadap lingkungan 100 persen dan untuk keterampilan berkomunikasi meningkat menjadi 96,29 persen.

\section{DAFTAR PUSTAKA}

Suherman, dkk. 2001. Keunggulan Metode Discovery ( Diakses) : http://herdy07.wordpress.com/2010/05/27/metode-pembelajaran- discoverypenemuan/ 